\title{
Proximate, Mineral, Vitamin Compositions, Mineral Safety Index and Mineral Ratios of the Flesh of Heterosexual Pairs of Neopetrolisthes maculatus
}

\section{Emmanuel llesanmi Adeyeye ${ }^{1}$ and Adubiaro Habibat Omolara ${ }^{2}$}

\author{
${ }^{1}$ Department of Chemistry (Analytical Unit), Ekiti State University, PMB 5363, Ado-Ekiti, Nigeria \\ ${ }^{2}$ Industrial Chemistry Department, Federal University, Oye Ekiti \\ eiadeyeye@yahoo.com, adeyeyeilesanmi2012@gmail.com
}

Keywords: Neopetrolisthes maculatus; heterosexual flesh; chemical composition

\begin{abstract}
The flesh of female and male Neopetrolisthes maculatus was used for the determination of proximate, minerals, vitamins compositions, mineral safety index (MSI) and mineral ratios (MRs). The values of crude fat, carbohydrate, total ash, moisture and fatty acid were more concentrated in the female than male sample. These parameters: crude protein, carbohydrate, total ash and moisture were relatively high in both samples. The coefficient of variation percent (CV \%) values ranged between 2.57 - 10.9 showing the value variations to be low. Both the total metabolisable energy and utilizable energy due to protein were higher in male than in female as

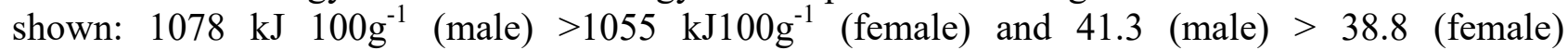
respectively. All the mineral levels in the female sample were higher than in the male sample. These

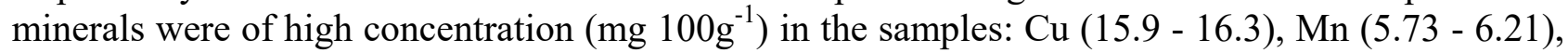
$\mathrm{Ca}(542$ - 562), Mg (652 - 682), K (317 - 329), Na (395 - 413) and P (1132-1143). Most of the mineral ratios were very low when compared to the ideal, those that were high were much higher than the ideal, and they were: $\mathrm{Ca} / \mathrm{Pb}(492631$ - 562195; ideal (id) $=84.0), \mathrm{Fe} / \mathrm{Pb}(1685-2083$; id $=4.40)$ and $\mathrm{K} / \mathrm{Co}(1919-2082$; id =2000) but values in $\mathrm{Zn} / \mathrm{Cd}$ and $\mathrm{Fe} / \mathrm{Co}$ were high but lower than the ideal values as shown: $\mathrm{Zn} / \mathrm{Cd}(207$ - 238; id =500) and Fe/Co (12.2-12.2; id =440). High mineral ratios were mainly observed in ratios involving trace elements. Mineral safety index of major concern in nutrition was observed in $\mathrm{Mg}$ and $\mathrm{Cu}$ in both samples. However the MSI aberration was more pronounced in the female than in the male. In the vitamin profiles niacin $\left(\mathrm{B}_{3}\right)$ was the only vitamin higher in value in male than female out of eleven vitamin parameters determined. $\mathrm{B}_{3}$ in male was just 3.48\% greater than in female whereas vitamins that had higher values in female than in male had higher percentage values that ranged between 4.22 - 15.0. All these parameters were significantly different at $r=0.01$ between the two samples: proximate, percentage energy distribution, mineral, mineral ratios and vitamin composition. On pairwise comparison, the parameters determined were more concentrated in the female than the male; this could be due to the biological function of the female as a "mother crab".
\end{abstract}

\section{Introduction}

Neopetrolisthes maculatus is a known spotted crab of two different colour forms. One form has carapace and white chelipeds having an uneven pattern of irregular sizes of red blotches; ambulatory legs also white, with some small red spots on meri of first pair (second pereopod). The other form has carapace and chelipeds with a uniform pattern of numerous small, reddish purple spots, meri of ambulatory legs also with numerous small, reddish purple spots [1].

Porcellanidae family consists of a group of crab-shaped anomuran crustaceans which belong to the super family Galatheoidea together with three other families Galatheidae, Munididae and Munidopsidae [2]. They mostly occur in rocky coral reefs of temperature and tropical coasts.

World Registers of Marine Species (WoRMS) has taxon details of Neopetrolisthes maculatus (H. Milne Edwards, 1837) [3]. Classification: Biota > Animalia (Kingdom) $>$ Arthropoda (Phylum) $>$ Crustacea (Subphylum) $>$ Multicrustacea (Superclass) $>$ Malacostracea (Class) > Eumalacostracea (Subclass) $>$ Eucarida (Superorder) $>$ Decapoda (Order) $>$ Pleocyemata 
(Suborder) $>$ Anomura (Infraorder) $>$ Galatheoidea $($ Superfamily) $>$ Porcellanidae (Family) $>$ Neopetrolisthes (Genus) > Neopetrolisthes maculatus (Species). Status: accepted. Rank: Species. Parent: Neopetrolisthes Miyake, 1937. Original name: Porcellana maculata H. Milne Edwards, 1837. Synonymized names [4]: Neopetrolisthes ohshimai Miyake, 1937 (Synonym). Petrolisthes ohshimai (Miyake, 1937) (junior synonym). Porcellana maculata H. Milne Edwards, 1837.

Porcellanids are widely distributed in the Indo-West Pacific. They come from east coast of Africa to Christmas Island and Western Australia, Bismarck Archipelago, Queensland, Moluccas, Palau, Taiwan, Southern Japan (Ryukyu Islands), New Caledonia, Marshall and Fiji Islands [5]. They are found in shallow subtidal water; coral and rocky reefs, where they are associated with large sea anemones (Cryptodendrum, Entacmaea, Gyrostoma, Heteractis and Stichodactyla), typically found in heterosexual pair [6].

$\mathrm{Crab}$ is consumed by many individuals as it is often recommended for pregnant women. There is paucity of information on the nutritional data of $N$. maculatus. Reported works in literature on crabs were: determination of the composition of nutritionally valuable parts of male and female common West African fresh water crab, Sudananautes africanus africanus [7]; relationship in the amino acid of the whole body, flesh and exoskeleton of S. africanus africanus [8]; proximate and mineral compositions of common crab species (Callinectes pallidus and Cardisoma armatum) of Badagry creek, Nigeria [10]; composition and distribution of the European green crab in Prince Edward Island, Canada[11] and the comparative study of lipid and fatty acid composition of two shell fish: lagoon and fresh water crabs[12]. We also have information on the amino acid profiles of the flesh of the heterosexual pairs of $N$. maculatus [13] and its chemical composition (proximate, minerals, vitamins), mineral ratios and mineral safety index of the innards of male and female $N$. maculatus [14]. The work reported in this article attempted to assess the comparative nutritional quality of both male and female $N$. maculatus flesh in terms of their proximate, mineral, vitamin compositions, mineral safety index (MSI) and mineral ratios (MRs).

\section{Materials and Methods}

Collection of samples: Wet samples were collected from catching centres from the Atlantic Ocean at Orimedu beach in Ibeju-Lekki area of Lagos, Lagos State, Nigeria. The samples were collected in June, 2015. The crabs were washed with distilled water to remove adhering contaminant and transported in ice crushed containers to the laboratory for authentication and preservation prior to analyses. The crabs were wrapped in alluminium foil and stored in a cool chamber of $<4^{0} \mathrm{C}$ for between 2-3 days before analyses. Meanwhile, they were iced to kill.

Sample treatment: About twelve matured crabs were collected at the catching centers but only three samples were used in the study. The three fresh whole crabs were two (males) and one (female). On separating the body parts, only the flesh was dried in the oven at $105^{\circ} \mathrm{C}$ for this research. However, the separated parts were the carapace and cheliped exoskeleton (to constitute the exoskeleton) and the muscle from the thoracic sterna and cheliped (to constitute flesh) whilst the internal organs were preserved for further analyses. The flesh from each sex was separately blended.

Proximate composition analysis: The micro-Kjeldahl method [15] was followed to determine the crude protein. The crude fat was extracted with chloroform/methanol $(2: 1 \mathrm{v} / \mathrm{v})$ mixture using Soxhlet extraction apparatus [16]. Moisture, ash and crude fibre determination followed AOAC [16] methods whilst carbohydrate was determined by difference. The calorific values in kilojoule (kJ) and kilocalorie ( $\mathrm{kcal}$ or $\mathrm{Cal}$ ) were calculated by multiplying the crude fat, protein and carbohydrate by Atwater factors of (kJ/kcal) 37/9, 17/4 and 17/4 respectively. Determinations were in duplicate.

Mineral composition analyses: The minerals were analysed from the solutions obtained by first dry ashing the samples at $550^{\circ} \mathrm{C}$. The filtered solutions were used to determine $\mathrm{Na}, \mathrm{K}, \mathrm{Mg}, \mathrm{Ca}, \mathrm{Fe}$, $\mathrm{Cu}, \mathrm{Co}, \mathrm{Mn}, \mathrm{Zn}, \mathrm{Pb}, \mathrm{Se}, \mathrm{Cd}$ and $\mathrm{Ni}$ by means of atomic absorption spectrophotometer (Buck Scientific Model -200A/210, Norwalk, Connecticut 06855) and phosphorus was determined 
colorimetrically by Spectronic 20 (Gallenkamp, UK) using the phosphovanado molybdate method [16]. All chemicals used were of British Drug House (BDH, London, UK) analytical grade. The detection limits for the metals in aqueous solutions had been determined previously using the methods of Varian Techtron [17]. The optimal analytical range was $0.1-0.5$ absorbance units with coefficients of variation from $0.9 \%-2.21 \%$.

Some calculations were made from the analytical results:

(i) Estimation of percentage energy contribution: The proportions of energy contribution from fat, protein and carbohydrate to total energy were calculated for each nutrient type. Values were reported in both $\mathrm{kJ} 100 \mathrm{~g}^{-1}$ and $\mathrm{kcal} 100 \mathrm{~g}^{-1}$. Also calculated was the utilization of energy due to protein (UEDP\%) in the samples.

(ii) Estimation of mineral ratios: Ratios of $\mathrm{Ca} / \mathrm{Mg}, \mathrm{Na} / \mathrm{K}, \mathrm{Ca} / \mathrm{K}, \mathrm{Na} / \mathrm{Mg}, \mathrm{Zn} / \mathrm{Cu}, \mathrm{Ca} / \mathrm{P}, \mathrm{Fe} / \mathrm{Cu}$, $\mathrm{Ca} / \mathrm{Pb}, \mathrm{Fe} / \mathrm{Pb}, \mathrm{Zn} / \mathrm{Cd}, \mathrm{Fe} / \mathrm{Co}, \mathrm{K} / \mathrm{Co}$ and $[\mathrm{K} /(\mathrm{Ca}+\mathrm{Mg})]$ were all calculated [18, 19 and 20].

(iii) Minerals safety index: The minerals safety index (MSI) were calculated [18] for minerals that have relevant standards for such determination. For the present work, MSI for these minerals were calculated: $\mathrm{Fe}, \mathrm{Ca}, \mathrm{P}, \mathrm{Mg}, \mathrm{Zn}, \mathrm{Cu}$, Se and $\mathrm{Na}$ using the formula:

\section{Calculated MSI $=$ MSI/RAI $x$ research data result}

where MSI = mineral safety index from the Table $($ standard $) ; \mathrm{RAI}=$ recommended adult intake.

(iv) Vitamins composition determination: The vitamins content of the samples were analysed following the modified methods of AOAC [16] [MTHD 992.03, 992.04 and 992.04 and 992.26]. The samples were made to attain laboratory atmospheric condition on the bench after being removed from the storage chamber at less than $4^{0} \mathrm{C}$. Each sample was pressed and completely homogenized in the mortar carefully with pestle to avoid forming balls. About $0.1 \mathrm{~g}$ of each sample was weighed into $10 \mathrm{ml}$ beaker capacity. The vitamins were extracted in the container by the above methods. The extracted vitamins solution was concentrated to $1.0 \mathrm{ml}$ for the chromatographic analysis. The GC conditions for the vitamin analysis were: GC: HP 5890 powered with HP ChemStation rev. A 09.01 (1206) software; injection type: split injection; split ratio: 20:1; carrier gas: nitrogen; inlet temperature: $250^{\circ} \mathrm{C}$; column type: HP 5; column dimensions: $30 \mathrm{~m} \times 0.25 \mathrm{~mm} \times$ $0.25 \mu \mathrm{m}$; oven programme: initial temperature at $50^{\circ} \mathrm{C}$, first ramping at $10^{0} \mathrm{C} \mathrm{min} \mathrm{m}^{-1}$ for $20 \mathrm{~min}$ $\left(250^{\circ} \mathrm{C}\right)$, maintained for $4 \mathrm{~min}$, second ramping at $15^{0} \mathrm{C} \mathrm{min}^{-1}$ for $4 \mathrm{~min}\left(310^{\circ} \mathrm{C}\right)$, maintained for 5 min; detector: PFPD; detector temperature: $320^{\circ} \mathrm{C}$; hydrogen pressure: 20 psi; compressed air: 30 psi. All determinations were in duplicate and on dry weight.

\section{Statistical Evaluation}

Data results in Tables 1,3,5,8 and 10 were subjected to statistical analyses of correlation coefficients $\left(r_{x y}\right)$, regression coefficients $\left(R_{x y}\right)$, coefficients of alienation $\left(C_{A}\right)$, index of forecasting efficiency (IFE), coefficient of determination of variance $\left(\mathrm{r}_{\mathrm{xy}}{ }^{2}\right)$. Other calculations made were grand mean, standard deviation (SD) and coefficients or variation (CV \%). The $r_{x y}$ values were converted to critical Table values to find out if significant differences existed among the two heterosexual pair sample results at $r_{=0.01}$ [21]. The $\mathrm{C}_{\mathrm{A}}$ and IFE values were obtained using the following formulae [22]:

$$
\begin{gathered}
\mathrm{C}_{\mathrm{A}}=\sqrt{1-\left(r_{x y}\right)^{2}} \\
\mathrm{IFE}=1-\sqrt{1-\left(r_{x y}\right)^{2}} \times 100
\end{gathered}
$$




\section{Results and Discussion}

Table 1 is the proximate composition values of the Neopetrolisthes maculatus male and female samples on dry weight. Major significant results were $\left(\mathrm{g} 100 \mathrm{~g}^{-1}\right)$ : protein $(40.2-43.7)$ having a CV\% of 5.91; total ash (26.5 - 28.0) with CV\% of 3.89; moisture (13.5 - 14.0) and CV\% value of 2.57; carbohydrate (10.9 - 12.2) with $\mathrm{CV} \%$ of 7.96. Moderate values of crude fat of 4.05 -

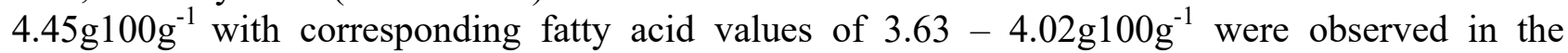
samples; their corresponding CV\% values were 6.66 and 7.21 respectively. Crude fibre had the lowest values of $1.20-1.40 \mathrm{~g} 100 \mathrm{~g}^{-1}$ and highest level of CV\% (10.9). The CV\% values were all generally low ranging from $2.57-10.9$ showing the close relationships on parameter basis of the proximate values in the two different $N$. maculatus sexes.

Table 1. Proximate composition $\left(\mathrm{g}_{100 \mathrm{~g}^{-1}}\right)$ of the female and the male flesh of Neopetrolisthes maculatus on dry weight basis

\begin{tabular}{|l|l|l|l|l|l|l|l|}
\hline Parameter & $\begin{array}{l}\text { Female } \\
\text { crab }\end{array}$ & $\begin{array}{l}\text { Male } \\
\text { crab }\end{array}$ & Mean & SD & CV\% & $\begin{array}{l}\text { Female } \\
\text { minus(-)male } \\
\text { values }\end{array}$ & $\begin{array}{l}\text { Percentage } \\
\text { differences }\end{array}$ \\
\hline Crude fat & 4.45 & 4.05 & 4.25 & 0.283 & 6.66 & +0.400 & +8.99 \\
\hline Crude protein & 40.2 & 43.7 & 41.9 & 2.47 & 5.91 & -3.50 & -8.72 \\
\hline Carbohydrate & 12.2 & 10.9 & 11.6 & 0.919 & 7.96 & +1.30 & +10.7 \\
\hline Total ash & 28.0 & 26.5 & 27.3 & 1.06 & 3.89 & +1.50 & 5.36 \\
\hline Crude fibre & 1.20 & 1.40 & 1.30 & 0.141 & 10.9 & -0.200 & -16.7 \\
\hline Moisture & 14.0 & 13.5 & 13.8 & 0.354 & 2.57 & +0.500 & +3.57 \\
\hline Fatty acid & 4.02 & 3,63 & 3.83 & 0.276 & 7.21 & +0.390 & +9.70 \\
\hline
\end{tabular}

${ }^{\mathrm{a}}$ Crude fat $\times \mathrm{XFA}=4.45 \times 0.927$ (female crab) and $4.05 \times 0.8975$ (male crab)

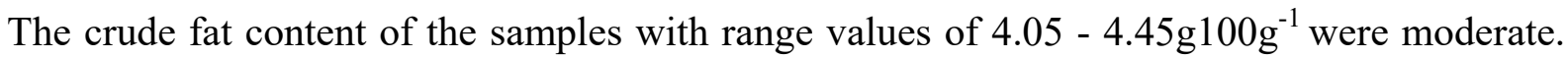
These levels of fat in the flesh of the crab samples were good for people who want to take low fat in their nutritional sources. The values of crude fat in these samples formed about one third of the values reported for both male and female $N$. maculatus innards. Crude fat values observed for $N$.

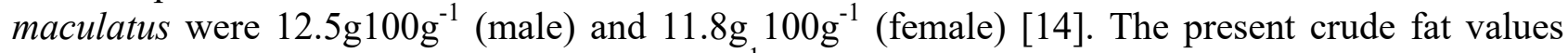
were close to the values of $5.15-6.25 \mathrm{~g} 100 \mathrm{~g}^{-1}$ in Acanthurus monroviae and Lutjanus goreensis fishes [23]; 7.48g100g-1 of the skin of Pellanula afzeliusis [24] and the value of $7.40 \mathrm{~g}^{-100 \mathrm{~g}^{-1}}$ in the skin of barracuda fish [25]. The crude fat when subjected to fatty acid values [crude fat $\times 0.927$

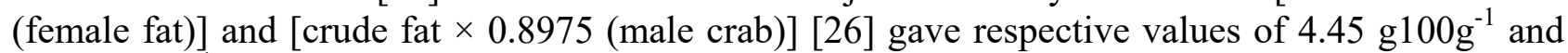
$4.05 \mathrm{~g}_{100 \mathrm{~g}^{-1}}$. This gave a ratio of $1.10: 1.00$ (total fatty acids) in female and male flesh of $N$. maculatus respectively.

The crude protein values of the flesh of $N$. maculatus at $40.2-43.7 \mathrm{~g} 100 \mathrm{~g}^{-1}$ were lower than the values in the innards of $N$. maculatus with values of $55.5 \mathrm{~g} 100 \mathrm{~g}^{-1}$ (female) and $56.8{\mathrm{~g} 100 \mathrm{~g}^{-1}}^{-1}$

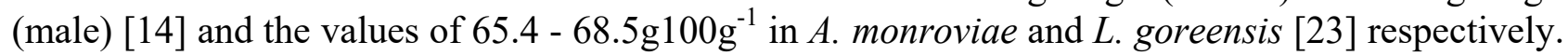
The present values were however higher than the literature values in some shell fishes: Callinectes

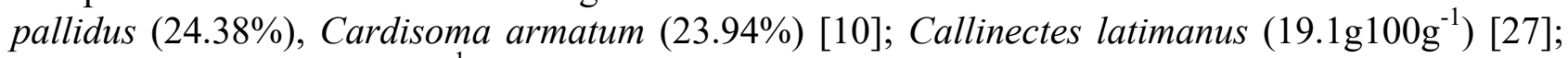

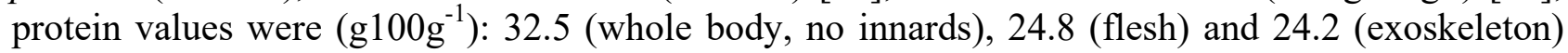
from the male body of Sudananautes africanus africanus [28]; 17.2 (whole body), 18.3 (flesh) and 19.1 (exoskeleton) from the body of Pandalus borealis[29]; however the present results fell within

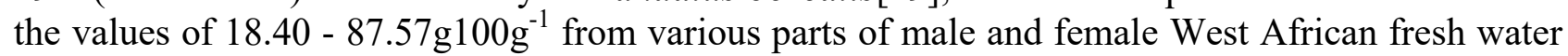
crab S. africanus africanus [7].

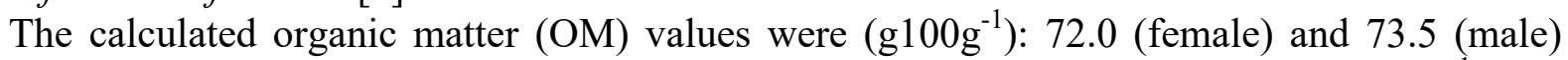
with corresponding total solid (TS) of 86.0 and 86.5. The OM values of $72.0-73.5 \mathrm{~g}^{100 \mathrm{~g}^{-1}}$ were lower than the values of 89.2 (male) and 87.0 (female) but about similar to corresponding total solid of 85.5 and 86.0 in the innards of $N$. maculatus [14]. Present values were also lower than the values reported for four fresh water fin fishes of Mormyrops delicious (86.4), Bagrus babayad (75.0), Synodontis budgetti (84.0) and Hemischronis faciatus (76.0) [30]; the values of $90.9-91.42{\mathrm{~g} 100 \mathrm{~g}^{-1}}^{-1}$

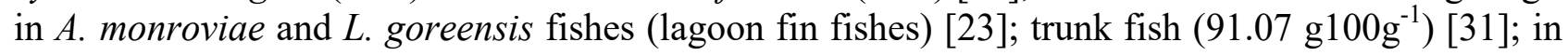




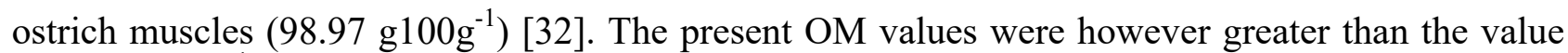

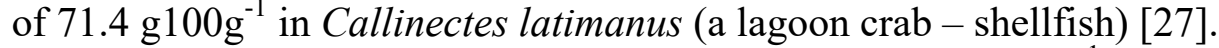

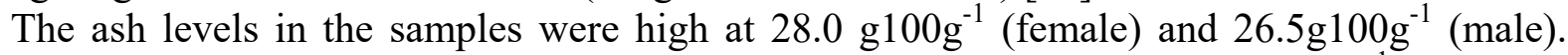
These values were about double of the values in the innard of the female $\left(13.0 \mathrm{~g} 100 \mathrm{~g}^{-1}\right)$ but three

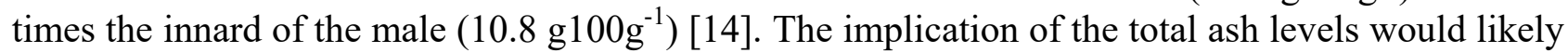
result in high levels of minerals in the samples. It has been observed that moderate level of protein would result into moderate levels of crude fat, total ash and low level of carbohydrate. While carbohydrate and crude fat were moderate in the present results, total ash was slightly high.

The differences that occurred in the parameter values of the samples were also depicted in the Table 1. Differences ranged between 3.57 to 16.7 in percentage values. Positive signs showed that female had higher value in that parameter whereas negative value meant that male had higher value. Seven parameters were compared in the proximate composition, five parameters or $5 / 7(71.4 \%)$ of the results were more positive towards the female sample whereas only two parameters or $2 / 7$ $(28.6 \%)$ were more positive towards the male sample. These preponderance of concentration values towards the female $N$. maculatus could be due to its function as a "mother crab".

In Table 2, we have the statistical evaluation of the results in Table 1. In the statistics, the following values were high: correlation coefficient $\left(\mathrm{r}_{\mathrm{xy}}\right)(0.9958)$; variance $\left(\mathrm{r}_{\mathrm{xy}}{ }^{2}\right)(0.9916), \mathrm{CV} \%$ (96.5, female) and 103 (male) and index of forecasting efficiency (IFE) (0.9084). The regression coefficient $\left(\mathrm{R}_{\mathrm{xy}}\right)$ value was a reflection of the female parameters being totally higher in values than the male; meaning that for every unit increase in the male parameter, there was a corresponding increase of 1.06 in the female crab parameter. Both male and female CV\% values were very high showing the high disparity in the overall concentrations of the parameters in the samples. The $r_{x y}$ was significant at $r=0.01$ since $r_{c}=0.9958>r_{T}=0.874$ at $n-2$ df $(d f=$ degree of freedom $)$ meaning that significant differences existed in the proximate composition of the two samples. The mean values were low at 14.8 (male) - 14.9 (female) with corresponding low values of standard deviation of $14.3-15.3$. The $\mathrm{C}_{\mathrm{A}}$ was low at 0.0916 or $9.16 \%$ with a corresponding high value for IFE at 0.9084 or $90.84 \%$. It is known that the higher the $\mathrm{C}_{\mathrm{A}}$, the lower the IFE and vice versa. Whilst $\mathrm{C}_{\mathrm{A}}$ is the error of prediction of relationship between two samples, the IFE is a reduction in the prediction of error of relationship. This meant that in this report the error of prediction was just $9.16 \%$ which could be regarded as low. Hence, the biochemical activities to be carried out by the male crab could also be carried out by the female crab of $N$. maculatus.

Table 2. Statistical analysis of the results from Table 1

\begin{tabular}{|l|l|l|l|}
\hline Statistics & Female crab & & Male crab \\
\hline $\mathrm{r}_{\mathrm{xy}}{ }^{2}$ & & 0.9958 & \\
\hline $\mathrm{r}_{\mathrm{xy}}{ }^{2}$ & & 0.9916 & \\
\hline Rxy & & 1.06 & \\
\hline Mean & 14.9 & & 14.8 \\
\hline $\mathrm{SD}$ & 14.3 & & 15.3 \\
\hline $\mathrm{CV} \%$ & 96.5 & & 103 \\
\hline $\mathrm{C}_{\mathrm{A}}$ & & 0.0916 & \\
\hline IFE & & 0.9084 & \\
\hline Remark & & $*$ & \\
\hline
\end{tabular}

$\mathrm{r}_{\mathrm{xy}}=$ correlation coefficient; Rxy $=$ regression coefficient; $\mathrm{C}_{\mathrm{A}}=$ coefficient of alienation; IFE $=$ index of forecasting efficiency; * results significantly different at $\mathrm{n}-2(\mathrm{df})(7-2=5)$ and $\mathrm{r}={ }_{0.01} ;\left[\mathrm{r}_{\mathrm{T}}=0.874\right.$ (critical value)].

Table 3 contained the proportions of percentage energy contribution from fat, protein and

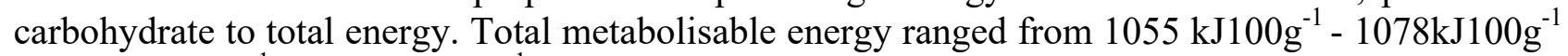

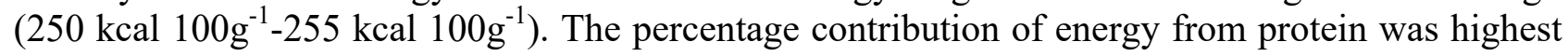
having values range of 64.7 - 68.9. The least percentage contribution came from fat at $38.8-41.3$. All the CV\% values were low at range values of $1.40-9.58$. The total metabolisable energy values here were lower than in the innards of $N$. maculatus where values of $1446-1493 \mathrm{~kJ}^{100 \mathrm{~g}^{-1}}$ were reported [14]; the values were also lower to $1438-1442 \mathrm{~kJ}^{-100 \mathrm{~g}^{-1}}$ reported in $A$. monroviae and $L$. 
goreensis [23]; 1.61-1.71 MJ 100 $\mathrm{g}^{-1}$ from eight organs of guinea-fowl [33]; sheep lean meat (2.06 $\left.\mathrm{MJ} 100 \mathrm{~g}^{-1}\right)$ and lean pork meat $\left(2.29 \mathrm{MJ} 100 \mathrm{~g}^{-1}\right)$ [34]; cereal values of $1.3-1.6 \mathrm{MJ}^{2} 00 \mathrm{~g}^{-1}[35]$. The present values were however close to the value of $1142 \mathrm{~kJ} 00 \mathrm{~g}^{-1}$ reported for C. latimanus [27]. The energy contribution trend was $\mathrm{PEP} \%>\mathrm{PEC} \%>\mathrm{PEF} \%$ which contrasted innards of $N$. maculatus in the position of $\mathrm{PEC} \%$ and $\mathrm{PEF} \%$ as shown: $\mathrm{PEP} \%>\mathrm{PEF} \%>\mathrm{PEC} \%$ [14]. The energy need of an adult depends on his physiological state and it ranges from 2500 - $3000 \mathrm{kcal}$; for the infant, energy requirement is $740 \mathrm{kcal}$ [36]. Going by the minimum energy value of adult requirement, a value of $1000 \mathrm{~g}$ female and $980 \mathrm{~g}$ male sample would be needed for daily energy supply whereas the values would be for infants at $296 \mathrm{~g}$ female and $290 \mathrm{~g}$ male. These values were higher than in these literature values: 704 - 845g (adults) and 208g (infants) of male innards of N. maculatus [14] whereas it was 727 - 872 g (adults) and 344g (infants) of female innards [14]; 733-880g (adults) and 220 (infant) of $A$. monroviae and 735 - 882g (adults) and 221g (infants) of L. goreensis [23]; from C. latimanus (915g, adults minimum) and (271g, infants)[27]; 786 - 944 (muscle) and 761 - 913 (skin) of turkey for adults requirement but 233g (muscle) and 325g (skin) for infants [37]; from guinea-fowl organs we have 649 - 733 (adult man) and 192g (infants) [33]. Despite the fact that the metabolisable energy from the flesh of $N$. maculatus was lower than the literature values, it can still be regarded as a moderate energy dense source. Finally in Table 3 was depicted the utilizable energy due to protein (UEDP\%) whose values range were $38.8-41.3$ (assuming $60 \%$ of protein energy utilization). It is interesting to note that these values were very close to the values of 38.8 39.1 observed for the innards of $N$. maculatus heterosexuals [14]. The present values were much higher than the recommended safe level of $8 \%$ for an adult man who requires about $55 \mathrm{~g}$ protein per day with $60 \%$ utilization. The following UEPD\% values were available in literature: $46.3-48.5$ in A. monroviae and L. goreensis fishes [23]; 56.4 (turkey muscle), 40.0 (turkey skin) [37]; lower values had however been observed in the followings: 12.1 - 28.8 (female and male exoskeleton), 12.1 - 23.5 (female and male flesh) and 13.8 - 17.9 (female and male whole body, no innards) of $S$. africanus africanus [9]; 17.1 in Callinectes latimanus [27]; 17.0 in the shell + head of Pandalus borealis [38]. When the samples serve mainly as the protein source in the diet of man, protein energy malnutrition in children and adults would be prevented; the samples would also be good to be used as fortifier in protein deficient cereal products. The PEF\% of 13.9 - 15.6 was about one-half of the value recommended level of 30\% [39] and slightly below one-half of 35\% [40] for total fat intake (assuming it serves as the only source of fat in the diet); this is good for people wishing to adopt the guidelines for a healthy diet.

Table 3. Proportions of percentage energy contribution from fat, protein and carbohydrate to total energy

\begin{tabular}{|c|c|c|c|c|c|}
\hline Parameter & $\begin{array}{l}\text { Female } \\
\text { crab }\end{array}$ & Male crab & Mean & SD & CV\% \\
\hline $\begin{array}{l}\text { Total energy }(\mathrm{E}) \\
\left(\mathrm{E} \text { in } \mathrm{kJ} 100 \mathrm{~g}^{-1}\right) \\
\left(\mathrm{E} \text { in kcal } 100 \mathrm{~g}^{-1}\right)\end{array}$ & $\begin{array}{l}1055 \\
250\end{array}$ & $\begin{array}{l}1078 \\
255\end{array}$ & $\begin{array}{l}1067 \\
253\end{array}$ & $\begin{array}{l}16.3 \\
3.54\end{array}$ & $\begin{array}{l}1.52 \\
1.40\end{array}$ \\
\hline 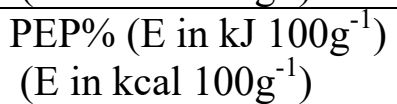 & $\begin{array}{l}64.7(683) \\
64.4(161)\end{array}$ & $\begin{array}{l}68.9(743) \\
68.6(175)\end{array}$ & $\begin{array}{l}66.8 \\
66.5\end{array}$ & $\begin{array}{l}2.97 \\
2.97\end{array}$ & $\begin{array}{l}4.45 \\
4.47\end{array}$ \\
\hline $\begin{array}{l}\text { PEC\% }\left(\mathrm{E} \text { in } \mathrm{kJ} 100 \mathrm{~g}^{-1}\right) \\
\left(\mathrm{E} \text { in } \mathrm{kcal} 100 \mathrm{~g}^{-1}\right)\end{array}$ & $\begin{array}{l}19.7(207) \\
19.5(48.8)\end{array}$ & $\begin{array}{l}17.2(185) \\
17.1(43.6)\end{array}$ & $\begin{array}{l}18.5 \\
18.3\end{array}$ & $\begin{array}{l}1.77 \\
1.70\end{array}$ & $\begin{array}{l}9.58 \\
9.27\end{array}$ \\
\hline $\begin{array}{l}\text { PEF\% }\left(\mathrm{E} \text { in } \mathrm{kJ}_{\left.100 \mathrm{~g}^{-1}\right)}\right. \\
\left(\mathrm{E} \text { in kcal } 100 \mathrm{~g}^{-1}\right)\end{array}$ & $\begin{array}{l}15.6(165) \\
16.0(40.1)\end{array}$ & $\begin{array}{l}13.9(150) \\
14.3(36.5)\end{array}$ & $\begin{array}{l}14.8 \\
15.2\end{array}$ & $\begin{array}{l}1.20 \\
1.20\end{array}$ & $\begin{array}{l}8.15 \\
7.93\end{array}$ \\
\hline $\begin{array}{l}\text { UEDP\% ( due to kJ) } \\
\text { (due to kcal) }\end{array}$ & $\begin{array}{l}38.8 \\
38.6\end{array}$ & $\begin{array}{l}41.3 \\
41.2\end{array}$ & $\begin{array}{l}40.2 \\
39.9\end{array}$ & $\begin{array}{l}1.77 \\
1.84\end{array}$ & $\begin{array}{l}4.41 \\
4.61\end{array}$ \\
\hline
\end{tabular}

$\mathrm{PEP}=$ proportion of total energy due to protein; $\mathrm{PEC}=$ proportion of total energy due to carbohydrate; $\mathrm{PEF}=$ proportion of total energy due to fat; UEDP = utilization of $60 \%$ of $\mathrm{PEP} \%$. 
Water is indispensable for the efficient utilization and conservation of food within the body [41], this is because the water content of the body changes with the type of diet [42]. The biochemical basis for this relationship arises from the fact that water deficit created by protein metabolism is about seven times that for equivalent calories of carbohydrates or fats. Hence, in young children an increase in calories from carbohydrate causes hydration, whereas an increase in calories from proteins causes dehydration [43]. The increased output of ketones and acids which accompanies a shift to high-fat diets is associated with increased water loss which can be offset by an increase in carbohydrate intake. The quality of protein can also influence the degree of tissue hydration. Albanese [44] had given the number of grammes of water required for complete metabolism of 100 calories of some food substances. Food materials (protein, starch and fat) all have pre-formed water of 0.00 in each case; water gained by oxidation: 10.3 (protein), 13.9 (starch) and 11.9 (fat); lost in dissipation of heat: 60.0 for each of the food material; water lost in excreting end products ( 1 calorie of protein requires $3.0 \mathrm{ml}$ of water for the excretion of urea and sulphate formed from it, $1 \mathrm{~g}$ of ash requires $65 \mathrm{ml}$ of water for the excretion): 300 (protein), both 0.00 in starch and fat; deficit: 350 (protein), 46 (starch) and 48 (fat). From Table 3, $161 \mathrm{kcallog}^{-1} \mathrm{energy}^{-}$ from female crab protein would require $483 \mathrm{ml}$ of water for complete metabolism whereas the male crab sample protein of $175 \mathrm{kcal} 100 \mathrm{~g}^{-1}$ energy would require $525 \mathrm{ml}$ of water for complete protein metabolism. Hence, whereas female crab flesh would have water deficit of $564 \mathrm{ml}$, male crab flesh would have water deficit of $613 \mathrm{ml}$ (noting that 100 calories have a water deficit of $350 \mathrm{ml}$ ). For the consumer of one of these samples in the diet, each would need slightly below one litre of water for consumption to avoid water deficit. In the innards that had more protein, energy from male crab

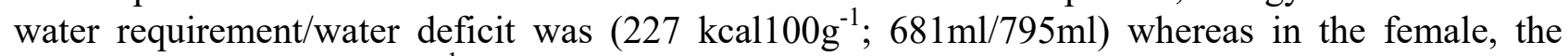

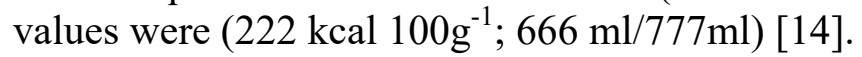

Table 4 contained the statistical evaluation of the data from Table 3 . These values were all high: $\mathrm{r}_{\mathrm{xy}}, \mathrm{r}_{\mathrm{xy}}{ }^{2}$, mean, standard deviations, $\mathrm{CV} \%$ and IFE. These values were very close or similar in the female and male statistical values: mean (239 - 244), SD (457 - 467) and CV\% (191-191). The IFE was very high at $99.49 \%$ making the prediction of relationship virtually error free (just $0.51 \%$ ) between the two heterosexuals. The $r=0.01$ showed $r_{c}=0.99999>r_{T}=0.959$, hence results were significantly different.

Table 4. Statistical analysis of the results from Table 3

\begin{tabular}{|l|l|l|l|}
\hline Statistics & Female crab & & Male crab \\
\hline $\mathrm{r}_{\mathrm{xy}}$ & & 0.99999 & \\
\hline $\mathrm{r}_{\mathrm{xy}}{ }^{2}$ & & 0.99997 & \\
\hline Rxy & & 1.02 & \\
\hline Mean & 239 & & 244 \\
\hline $\mathrm{SD}$ & 457 & & 467 \\
\hline $\mathrm{CV} \%$ & 191 & & 191 \\
\hline $\mathrm{C}_{\mathrm{A}}$ & & 0.0051 & \\
\hline IFE & & 0.9949 & \\
\hline Remark & & $*$ & \\
\hline
\end{tabular}

Results significantly different at $\mathrm{n}-2(\mathrm{df})(5-2=3)$ and $\mathrm{r}={ }_{0.01} ;\left[\mathrm{r}_{\mathrm{T}}=0.959\right.$ (critical value) $]$.

Table 5 contained the mineral values of the samples. The total mineral values in the samples were $3156 \mathrm{mg} 100 \mathrm{~g}^{-1}$ (female) $>3063 \mathrm{mg} 00 \mathrm{~g}^{-1}$ (male). Minerals of major significance in both samples were: $\mathrm{P}>\mathrm{Mg}>\mathrm{Ca}>\mathrm{Na}>\mathrm{K}>\mathrm{Cu}>\mathrm{Mn}>\mathrm{Fe}>\mathrm{Zn}$. For these minerals, the value ranges were $\left(\mathrm{mg} 100 \mathrm{~g}^{-1}\right)$ : P (1132 - 1143, 37.0 - 36.2\%); $\mathrm{Mg}(652$ - 682, 21.8 - 21.6\%); Ca (542 - 562, 17.7 - 17.8\%); Na (395 - 413, 12.9 - 13.1\%); K (317 - 329, 10.3 - 10.4\%); Cu (15.9 - 16.3, 0.5191 $0.5166 \%)$; Mn (5.73 - 6.21, $0.1871-0.1968 \%)$; Fe (1.85 - 2.08, $0.0604-0.0659 \%)$ and $\mathrm{Zn}(1.43-$ $1.53,0.0467-0.0453 \%$ ). Low values were observed for $\mathrm{Co}$, Fe and $\mathrm{Ni}$ whilst $\mathrm{Pb}$, Se and $\mathrm{Cd}$ were in traces. $\mathrm{Pb}$ and $\mathrm{Cd}$ are not useful for the human metabolism nutritionally and it is good they were in trace amount; however their presence could be due to the onset of pollution of the water. The 
current results were highly comparable to the results of minerals observed for the innards of $N$. maculatus [14]; values: $\mathrm{P}(969$ - 1144) $>\mathrm{Mg}(594$ - 614) $>\mathrm{Ca}(428$ - 446) $>\mathrm{Na}(349-390)>\mathrm{K}$ $(280-322)>\mathrm{Cu}(17.4-18.6)>\mathrm{Mn}(5.32-8.53)>\mathrm{Fe}(2.13-2.36)>\mathrm{Zn}(1.79-1.95)$ with values being constantly higher in the female than the male. In the male, female and berried female of Charybdis lucifera (a marine crab), the mineral concentration trend was $\mathrm{Na}>\mathrm{K}>\mathrm{Mg}>\mathrm{Ca}>\mathrm{Mn}>$ $\mathrm{Fe}>\mathrm{Zn}$ whereas $\mathrm{Cu}, \mathrm{Hg}$ and $\mathrm{Cd}$ were in traces (but $\mathrm{P}$ was not determined). The total minerals concentration in the three samples under reference had this trend $\left(\mathrm{mg} 100 \mathrm{~g}^{-1}\right.$ on wet weight basis): male $(95.5 \pm 2.20)<$ female $(121.76 \pm 2.13)<$ berried female $(156.24 \pm 1.13)$ [45]. Fourteen minerals were determined in each of the present samples.

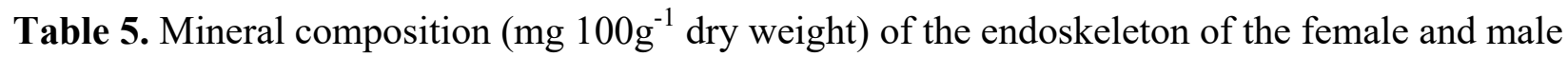
Neopetrolisthes maculatus

\begin{tabular}{|l|l|l|l|l|l|l|l|}
\hline Mineral & Female crab & Male crab & Mean & SD & CV\% & Female-male values & \% difference \\
\hline $\mathrm{Fe}$ & 2.08 & 1.85 & 1.97 & 0.163 & 8.27 & +0.2302 & +11.1 \\
\hline $\mathrm{Cu}$ & 16.3 & 15.9 & 16.1 & 0.223 & 1.38 & +0.3149 & +1.94 \\
\hline $\mathrm{Co}$ & 0.1713 & 0.1521 & 0.1617 & 0.014 & 8.40 & +0.0192 & +11.2 \\
\hline $\mathrm{Mn}$ & 6.21 & 5.73 & 5.97 & 0.344 & 5.76 & +0.4867 & +7.83 \\
\hline $\mathrm{Zn}$ & 1.53 & 1.43 & 1.48 & 0.071 & 4.78 & +0.0999 & +6.54 \\
\hline $\mathrm{Pb}$ & 0.0010 & 0.0011 & 0.0011 & $7.07 \mathrm{e}-5$ & 6.73 & -0.0001 & -10.0 \\
\hline $\mathrm{Ca}$ & 562 & 542 & 552 & 14.4 & 2.60 & +20.3 & +3.61 \\
\hline $\mathrm{Mg}$ & 682 & 652 & 667 & 21.2 & 3.18 & +30.0 & +4.40 \\
\hline $\mathrm{K}$ & 329 & 317 & 323 & 8.59 & 2.66 & +12.1 & +3.69 \\
\hline $\mathrm{Na}$ & 413 & 395 & 404 & 12.3 & 3.05 & +17.4 & +4.22 \\
\hline $\mathrm{P}$ & 1143 & 1132 & 1137 & 8.04 & 0.707 & +11.4 & +0.995 \\
\hline $\mathrm{Se}$ & 0.0492 & 0.0420 & 0.0456 & 0.005 & 11.2 & +0.0072 & +14.6 \\
\hline $\mathrm{Cd}$ & 0.0074 & 0.0060 & 0.0067 & $9.90 \mathrm{e}-4$ & 14.8 & +0.0014 & +18.9 \\
\hline $\mathrm{Ni}$ & 0.1822 & 0.1631 & 0.1727 & 0.014 & 7.82 & +0.0191 & +10.5 \\
\hline $\mathrm{Total}$ & 3156 & 3063 & 3109 & 65.2 & 2.10 & +92.3 & +2.92 \\
\hline
\end{tabular}

Differences in the mineral values were shown in Table 5. Differences in percentage values ranged from 0.995 - 18.9 with the least difference coming from $\mathrm{P}$ and the highest came from $\mathrm{Cd}$. Out of the 15 parameters whose differences were calculated, 14 or 14/15 (93.3\%) had values more positive towards female whereas 1 or $1 / 5(6.67 \%)$ had value more positive towards the male crab sample. The concentration of minerals in crabs are known to be influenced by a number of factors that include seasonal and biological differences (species, size, age, sex and sexual maturity), food and food source and environment (water chemistry, salinity, temperature and contaminants) [46]. The sex mineral differences observed could be due to the reproductive state and metabolism.

$\mathrm{Fe}$ is an essential trace element as it has several vital functions in the human system. Fe in haemoglobin serves to carry oxygen to tissues from the lungs. Adequate Fe in the diet is very important for reducing the incidence of anemia particularly in young children. Deficiency in Fe may occur when demand for Fe is high like in growth, high menstrual loss and pregnancy and the intake is quantitatively inadequate or contains elements that render the Fe unavailable for absorption [47]. When the amount of $\mathrm{Ca}$ is adequate in the diet, Fe is utilized to better advantage; this is an instance of sparing action [48]. Transition metal ions, particularly $\mathrm{Cu}$ and $\mathrm{Fe}$ have been known as the major catalysts for oxidation [49]. $\mathrm{Cu}$ and $\mathrm{Fe}$ are important minerals found in fish as respiratory pigment, whereas $\mathrm{Co}$ is a constituent of vitamin $\mathrm{B}_{12}$.

$\mathrm{Ca}$ and $\mathrm{P}$ are always found together in the body, both contributing to the supportive structures of the body. $\mathrm{Ca}$ in these samples ranged as $542-562 \mathrm{mg}^{-100 \mathrm{~g}^{-1}}(17.7-17.8 \%)$. In C. lucifera, $\mathrm{Ca}$

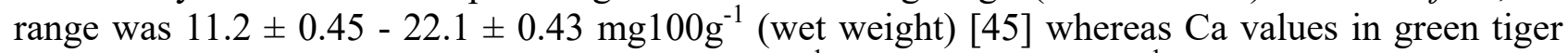

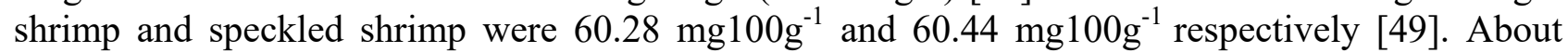
$1.9 \% \mathrm{Ca}$ is available in the human body and provides rigidity to the skeleton and plays important role in many metabolic processes [50]. Ca plays essential role in blood clotting, muscle contraction, nerve transmission, hard tissue structure, osmoregulation and as a cofactor for enzymatic processes. 
In premoult period of $C$. pagurus, hepatopancreas accumulates $\mathrm{Ca}$ that is likely used in the exoskeleton calcification [51].

Phosphorus is present in cells and in the blood as soluble phosphate ion, also present in lipids, proteins, carbohydrates and in energy transfer enzymes [52]. Phosphorus is also an essential component in nucleic acids and nucleoproteins responsible for cell division, reproduction and the transmission of hereditary traits [53]. Phosphorus was the most concentrated mineral in the samples

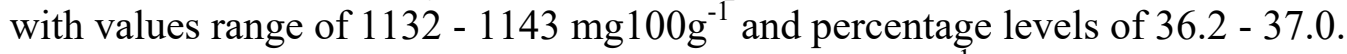

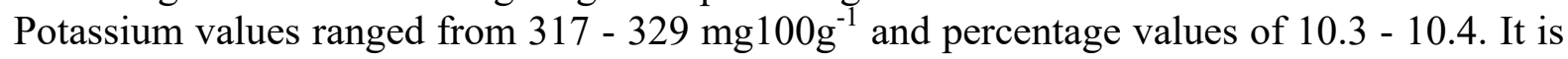
primarily an intracellular cation, in large part it is bound to protein and with sodium influences osmotic pressure and contributes to normal $\mathrm{pH}$ equilibrium [54]. Plants and animal tissues are both rich sources of $\mathrm{K}$, thus a dietary lack is seldom found. Sodium is a trace element in plants whereas $\mathrm{K}$ is much higher, hence $\mathrm{K}$ will reduce the deleterious effect of $\mathrm{Na}$ in the presence of higher level of $\mathrm{K}$. Potassium is also involved in the storage and transfer of energy and nucleotide synthesis. Sodium was more concentrated in the samples than potassium. The sodium values range of 395 $413 \mathrm{mglNog}^{-1}(12.9-13.1 \%)$ were observed in the samples. Sodium is the principal cation of the extracellular fluid and regulator of its volume. Sodium also helps to maintain the acid-base balance and essential for nerve system. The range of total percentage of $\mathrm{Na}+\mathrm{K}$ was 23.2 - 23.5.

Magnesium is important for human nutrition and it is required for the body's enzyme system. In concentration, $\mathrm{Mg}$ was next to $\mathrm{P}$ in the present samples having values of $652-682 \mathrm{mg} 100 \mathrm{~g}^{-1}$ and percentage levels of 21.6 - 21.8. In addition to maintaining bone health, $\mathrm{Mg}$ acts in all cells of soft tissues, where it forms part of protein-making machinery and necessary for energy metabolism. Magnesium is a co-factor for enzyme systems [54]. Manganese is important for the development of bones. It also acts as an activator of enzyme systems. Manganese had values range of 5.73-6.21 $\mathrm{mg} 100 \mathrm{~g}^{-1}$ in the samples, its value being about double the value of $\mathrm{Fe}$ in the samples but about four times the values of $\mathrm{Zn}$ in the samples. Zinc is an essential trace element for all living species because it is an important component of several enzymes and plays an essential role in a number of biological processes involved in growth and development [50]. MacFarlane et al. [55] reported higher $\mathrm{Cu}$ and $\mathrm{Zn}$ accumulation in females than males of semaphore crab, Helioecious cordiformis just as observed in the present research.

Table 6 has the statistical analysis of the results from Table 5. The values of $r_{x y}, r_{x y}{ }^{2}$, mean, standard deviation, $\mathrm{CV} \%$ and IFE were high. $\mathrm{R}_{\mathrm{xy}}$ value showed the male values were increasing by $0.9789 \mathrm{mg} 100 \mathrm{~g}^{-1}$ as female values were increasing by $1.00 \mathrm{mg} 100 \mathrm{~g}^{-1}$. Because $\mathrm{C}_{\mathrm{A}}$ was low, error of prediction of relationship was also low and the overall results were significantly different at $r=0.01$.

Table 6. Statistical analysis of the results from Table 5

\begin{tabular}{|l|l|l|l|}
\hline Statistics & Female crab & & Male crab \\
\hline $\mathrm{r}_{\mathrm{xy}}$ & & 0.9998 & \\
\hline $\mathrm{r}_{\mathrm{xy}}{ }^{2}$ & & 0.9997 & \\
\hline Rxy & & 0.9789 & \\
\hline Mean & 225 & & 219 \\
\hline $\mathrm{SD}$ & 357 & & 357 \\
\hline CV\% & 158 & & 163 \\
\hline $\mathrm{C}_{\mathrm{A}}$ & & 0.0183 & \\
\hline IFE & & 0.9817 & \\
\hline Remark & & $*$ & \\
\hline
\end{tabular}

Results significantly different at $\mathrm{n}-2(\mathrm{df})(14-2=12) \mathrm{r}_{=0.01} ;\left[\mathrm{r}_{\mathrm{T}}=0.661\right.$ (critical value) $]$.

The mineral ratios were shown in Table 7. Mineral ratios are often more important than the individual mineral levels themselves and this had been illustrated by the statements by Vitale et al. as quoted by Watts [19]: "Determining nutritional interrelationships is much more than knowing mineral levels alone. From a global stand point, although dietary deficiency is at the more serious end of the spectrum, the opposite end, dietary excess and aberrations contribute to the burden of disease." "Mild and subclinical deficiencies of nutrients outnumber overt syndromes ten to one." 
Significant ratios calculated include calculations of the following mineral relationships: $\mathrm{Ca} / \mathrm{P}, \mathrm{Na} / \mathrm{K}$, $\mathrm{Ca} / \mathrm{K}, \mathrm{Zn} / \mathrm{Cu}, \mathrm{Ca} / \mathrm{Mg}, \mathrm{Na} / \mathrm{Mg}$ and $\mathrm{Fe} / \mathrm{Cu}$. These select mineral ratios revealed not only the important balance between these elements, but they also provided information regarding the many possible factors that may be represented by a disruption of their relationships, such as disease states, physiological and developmental factors, the effects of diet, drugs, would also predispose a person with parasymphatetic dominance to certain health conditions if severe or chronic [19].

Table 7. Calculated mineral ratios of the endoskeleton of $N$. maculatus heterosexuals

\begin{tabular}{|l|l|l|l|l|l|l|l|}
\hline Parameter & $\begin{array}{l}\text { Ref. } \\
\text { balance) } \\
\text { Ideal }\end{array}$ & $\begin{array}{l}\text { Acceptable } \\
\text { ideal range }\end{array}$ & $\begin{array}{l}\text { Female } \\
\text { crab }\end{array}$ & $\begin{array}{l}\text { Male } \\
\text { crab }\end{array}$ & Mean & SD & CV\% \\
\hline $\mathrm{Ca} / \mathrm{Mg}$ & 7.00 & 3 to 11 & 0.8242 & 0.8310 & 0.828 & 0.005 & 0.578 \\
\hline $\mathrm{Na} / \mathrm{K}$ & 2.40 & 1.4 to 3.4 & 1.26 & 1.25 & 1.25 & 0.004 & 0.319 \\
\hline $\mathrm{Ca} / \mathrm{K}$ & 4.20 & 2.2 to 6.2 & 1.71 & 1.71 & 1.71 & 0.001 & 0.060 \\
\hline $\mathrm{Na} / \mathrm{Mg}$ & 4.00 & 2 to 6 & 0.6051 & 0.6063 & 0.606 & 0.0008 & 0.133 \\
\hline $\mathrm{Zn} / \mathrm{Cu}$ & 8.00 & 4 to 12 & 0.0940 & 0.0896 & 0.092 & 0.003 & 3.40 \\
\hline $\mathrm{Ca} / \mathrm{P}$ & 2.60 & 1.5 to 3.6 & 0.4918 & 0.4788 & 0.485 & 0.009 & 1.89 \\
\hline $\mathrm{Fe} / \mathrm{Cu}$ & 0.90 & 0.2 to 1.6 & 0.1281 & 0.1162 & 0.122 & 0.008 & 6.89 \\
\hline $\mathrm{Ca} / \mathrm{Pb}$ & 84.0 & 126 to 168 & 562195 & 492631 & 527413 & 49189 & 9.33 \\
\hline $\mathrm{Fe} / \mathrm{Pb}$ & 4.40 & 6.60 to 8.80 & 2083 & 1685 & 1884 & 282 & 15.0 \\
\hline $\mathrm{Zn} / \mathrm{Cd}$ & 500 & 750 to 1000 & 207 & 238 & 222 & 22.3 & 10.0 \\
\hline $\mathrm{Fe} / \mathrm{Co}$ & 440 & $-{ }^{a}$ & 12.2 & 12.2 & 12.2 & 0.00 & 0.00 \\
\hline $\mathrm{K} / \mathrm{Co}$ & 2000 & - & 1919 & 2082 & 2001 & 115 & 5.76 \\
\hline$[\mathrm{K} / \mathrm{Ca}+\mathrm{Mg})]$ & 2.2 & - & 0.5285 & 0.5304 & 0.529 & 0.001 & 0.256 \\
\hline
\end{tabular}

${ }_{-}=$not available

For the understanding of the mineral ratios, let us explain in detail the example of $\mathrm{Na} / \mathrm{K}$ ratio. For $\mathrm{Na} / \mathrm{K}$ ratio-Ideally there should be a $2.4: 1$ ratio of sodium relative to potassium with a range of 1.4 to 3.4 being acceptable. The sample results gave ratios of 1.25-1.26 which were below the ideal range. All the significant ratios have their values in the results being less than the ideal and also not falling within the acceptable ideal range. This is similar to the observations in the innards of $N$. maculatus [14]. Toxic metal ratios in these results were $\mathrm{Fe} / \mathrm{Pb}, \mathrm{Ca} / \mathrm{Pb}$ and $\mathrm{Zn} / \mathrm{Cd}$ whilst additional ratios were $\mathrm{Fe} / \mathrm{Co}$ and $\mathrm{K} / \mathrm{Co}$. In nutrition, the $[\mathrm{K} / \mathrm{Ca}+\mathrm{Mg})]$ values are very important. These ratios are being reported solely for the purpose of gathering research data. Mineral ratios analyses have been very useful in analysis of hair as a biochemical marker.

The mineral safety index (MSI) whose standards were available were calculated and shown in Table 8. The MSI standard values (TV of MSI, TV = Table value) were shown in column three of Table 8. For the sake of understanding the MSI calculation, an example will suffice; taking Ca as an example we have: the recommended adult intake (RAI) of $\mathrm{Ca}$ is $1200 \mathrm{mg}$, its minimum toxic dose (MTD) is $12000 \mathrm{mg}$ or 10 times the recommended daily average (RDA) which is equivalent to MSI of Ca. This is the reasoning for the other minerals. 
Table 8. Mineral safety index (MSI) of $\mathrm{Fe}, \mathrm{Ca}, \mathrm{P}, \mathrm{Mg}, \mathrm{Zn}, \mathrm{Cu}$, Se and $\mathrm{Na}$ of N. maculatus heterosexual endoskeleton

\begin{tabular}{|l|l|l|l|l|l|l|l|l|l|l|l|}
\hline Mineral & \multirow{2}{*}{$\begin{array}{l}\text { RAI } \\
(\mathrm{mg})\end{array}$} & $\begin{array}{l}\text { TV of } \\
\text { MSI }\end{array}$ & \multicolumn{3}{|c|}{ Female crab } & \multicolumn{3}{c|}{ Male crab } & Mean & SD & CV\% \\
\cline { 4 - 11 } & & & CV & D & $\% \mathrm{D}$ & CV & D & $\% \mathrm{D}$ & & & \\
\hline $\mathrm{Fe}$ & 15 & 6.70 & 0.9305 & 5.77 & 86.1 & 0.8277 & 5.87 & 87.6 & 0.8791 & 0.0727 & 8.27 \\
\hline $\mathrm{Ca}$ & 1200 & 10.0 & 4.68 & 5.32 & 53.2 & 4.52 & 5.48 & 45.2 & 4.60 & 0.120 & 2.60 \\
\hline $\mathrm{P}$ & 1200 & 10.0 & 9.53 & 0.47 & 4.70 & 9.43 & 0.57 & 5.70 & 9.48 & 0.067 & 0.707 \\
\hline $\mathrm{Mg}$ & 400 & 15.0 & 25.6 & -10.6 & -70.7 & 24.5 & -9.50 & -63.3 & 25.0 & 0.795 & 3.18 \\
\hline $\mathrm{Zn}$ & 15 & 33.0 & 3.36 & 29.6 & 89.8 & 3.14 & 29.9 & 90.5 & 3.25 & 0.155 & 4.78 \\
\hline $\mathrm{Cu}$ & 3 & 33.0 & 179 & -146 & -442 & 175 & -142 & -430 & 177 & 2.45 & 1.38 \\
\hline $\mathrm{Se}$ & 0.07 & 14.0 & 9.84 & 4.16 & 29.7 & 8.40 & 5.60 & 40.0 & 9.12 & 1.02 & 11.2 \\
\hline $\mathrm{Na}$ & 500 & 4.80 & 3.96 & 0.84 & 17.5 & 3.80 & 1.00 & 20.8 & 3.88 & 0.118 & 3.05 \\
\hline
\end{tabular}

$\mathrm{CV}=$ calculated value; $\mathrm{TV}=$ Table value $; \mathrm{D}=$ difference; $\mathrm{RAI}=$ recommended adult intake. No MSI standard for $\mathrm{K}, \mathrm{Mn}, \mathrm{Co}$ and $\mathrm{Pb}$.

$\mathrm{Mg}$ and $\mathrm{Cu}$ were the only minerals in both samples whose MSI values were greater than the standard values thereby resulting in negative differences whilst all others gave positive differences. The negative difference value in $\mathrm{Mg}$ was $-10.6(-70.7 \%)$ in the female and $-9.50(-63.3 \%)$ in the male; this meant the female crab might overload the consumer to the tune of $70.7 \%(\mathrm{Mg})$ and the male to the tune of $63.3 \%(\mathrm{Mg})$. $\mathrm{Cu}$ overload was worse with $-146(-442 \%)$ female and $-142(-$ $430 \%$ ) male. The negative calculated MSI values were also observed at high levels in the innards of N. maculatus [14]. In these samples $\mathrm{Cu}$ concentration was beyond being a trace element. Those calculated MSI < standard MSI meant that such minerals would not constitute mineral overload nor become toxic to the samples consumers. The very high levels of $\mathrm{Cu}$ might impair the metabolism of $\mathrm{Fe}, \mathrm{Zn}$ and $\mathrm{Mn}$. The CV\% values in Table 8 ranged from $0.707-11.2$ showing the MSI values to be close between the two samples.

Statistical evaluation of the results in Table 8 could be seen in Table 9. These values were high as earlier observed in earlier statistical results: $r_{x y}, r_{x y}{ }^{2}$, standard deviation, CV\% and IFE. Rxy $<1.00$ but mean and coefficient of alienation $\left(\mathrm{C}_{\mathrm{A}}\right)$ were low. At $r=0.01$, the results were significantly different.

Table 9. Statistical analysis of the results from Table 8

\begin{tabular}{|l|l|l|l|}
\hline Statistics & Female crab & & Male crab \\
\hline $\mathrm{r}_{\mathrm{xy}}$ & & 0.99997 & \\
\hline $\mathrm{r}_{\mathrm{xy}}{ }^{2}$ & & 0.99995 & \\
\hline Rxy & & 0.9789 & \\
\hline Mean & 29.6 & & 28.7 \\
\hline SD & 60.8 & & 59.6 \\
\hline CV\% & 205 & & 208 \\
\hline$C_{\mathrm{A}}$ & & 0.0072 & \\
\hline IFE & & 0.9928 & \\
\hline Remark & & $*$ & \\
\hline
\end{tabular}

Results significantly different at $\mathrm{n}-2(\mathrm{df})(8-2=6) \mathrm{r}_{=0.01} ;\left[\mathrm{r}_{\mathrm{T}}=0.834\right.$ (critical value)].

The vitamins composition of the samples were shown in Table 10. Vitamins of significance were $\left(\mathrm{mg} 100 \mathrm{~g}^{-1}\right): \mathrm{B}_{3}$ (niacin), 2.94 - 3.04; vitamin $\mathrm{C}$ (ascorbic acid), 6.98-7.59; vitamin $\mathrm{E}$ (tocopherol), 1.18-1.34; $\mathrm{B}_{6}$ (pyridoxamine), $1.34 \mathrm{e}-1$ to $1.42 \mathrm{e}-1 ; \mathrm{B}_{1}$ (thiamine), $1.11 \mathrm{e}-1$ to $1.22 \mathrm{e}-1$; $\mathrm{B}_{2}$ (riboflavin), $2.32 \mathrm{e}-1$ to $2.62 \mathrm{e}-1$ and $\mathrm{B}_{5}$ (pantothenic acid), 3.44 e-1 to 3.73 e- 1 with total range being 12.1 (male) -12.8 (female). All the CV\% levels were below $10.0 \%$ showing that the 
parameter values were close. The differences between the values of each vitamin were determined; we have 12 parameters. Of these 12 vitamins 11 of them or 11/12 (91.7\%) were more concentrated in the female sample whilst only one parameter $\left(\mathrm{B}_{3}\right)$ was more concentrated in the male than female; this difference was just 3.48\%; this being the least difference in the vitamins among the samples. The vitamin levels being more concentrated in the female sample than the male were in conformity with the observations made in the innards of N. maculatus [14].

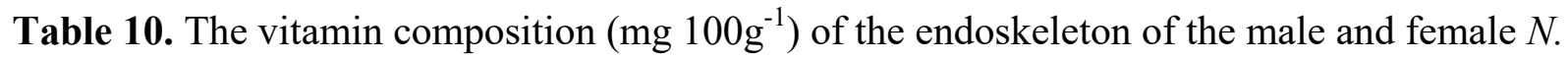
maculatus on dry weight basis

\begin{tabular}{|l|l|l|l|l|l|l|l|}
\hline Parameter & $\begin{array}{l}\text { Male } \\
\text { crab }\end{array}$ & $\begin{array}{l}\text { Female } \\
\text { crab }\end{array}$ & Mean & SD & CV\% & $\begin{array}{l}\text { Male- female } \\
\text { values }\end{array}$ & $\begin{array}{l}\% \\
\text { difference }\end{array}$ \\
\hline $\mathrm{B}_{3}$ (Niacin) & 3.04 & 2.94 & 2.99 & 0.075 & 2.50 & $+1.06 \mathrm{e}-1$ & +3.48 \\
\hline $\mathrm{B}_{4}$ (Adenine) & $3.44 \mathrm{e}-3$ & $3.58 \mathrm{e}-3$ & $3.51 \mathrm{e}-3$ & 0.0001 & 2.93 & $-1.45 \mathrm{e}-4$ & -4.22 \\
\hline $\mathrm{B}_{6}$ (Pyridoxamine) & $1.34 \mathrm{e}-1$ & $1.42 \mathrm{e}-1$ & $1.38 \mathrm{e}-1$ & 0.006 & 4.30 & $-8.37 \mathrm{e}-3$ & -6.27 \\
\hline $\mathrm{C}$ (Ascorbic acid) & 6.98 & 7.59 & 7.29 & 0.430 & 5.91 & $-6.09 \mathrm{e}-1$ & -8.72 \\
\hline $\mathrm{A}$ (Retinol) & $5.84 \mathrm{e}-2$ & $6.55 \mathrm{e}-2$ & $6.19 \mathrm{e}-2$ & 0.005 & 8.02 & $-7.03 \mathrm{e}-3$ & -12.0 \\
\hline $\mathrm{B}_{1}$ (Thiamine) & $1.11 \mathrm{e}-1$ & $1.22 \mathrm{e}-1$ & $1.17 \mathrm{e}-1$ & 0.008 & 7.06 & $-1.16 \mathrm{e}-2$ & -10.5 \\
\hline $\mathrm{B}_{2}$ (Riboflavin) & $2.32 \mathrm{e}-1$ & $2.62 \mathrm{e}-1$ & $2.47 \mathrm{e}-1$ & 0.021 & 8.52 & $-2.97 \mathrm{e}-2$ & -12.8 \\
\hline $\mathrm{E}$ (Tocopherol) & 1.18 & 1.34 & 1.26 & 0.114 & 9.03 & $-1.61 \mathrm{e}-1$ & -13.6 \\
\hline $\mathrm{B}_{9}$ (Folic acid) & $4.07 \mathrm{e}-7$ & $4.54 \mathrm{e}-7$ & $4.30 \mathrm{e}-7$ & $3.3 \mathrm{e}-8$ & 7.56 & $-4.6 \mathrm{e}-8$ & -11.3 \\
\hline $\mathrm{K}$ (Phylloquinone) & $8.32 \mathrm{e}-4$ & $9.56 \mathrm{e}-4$ & $9.40 \mathrm{e}-4$ & $8.81 \mathrm{e}-5$ & 9.85 & $-1.25 \mathrm{e}-4$ & -15.0 \\
\hline $\begin{array}{l}\mathrm{B}_{5} \text { (Pantothenic } \\
\text { acid) }\end{array}$ & $3.44 \mathrm{e}-1$ & $3.73 \mathrm{e}-1$ & $3.59 \mathrm{e}-1$ & 0.021 & 5.81 & $-2.95 \mathrm{e}-2$ & -8.57 \\
\hline Totals & 12.1 & 12.8 & 12.5 & 0.531 & 4.26 & $-7.50 \mathrm{e}-1$ & -6.21 \\
\hline
\end{tabular}

Deficiency syndromes may occur when the body does not get adequate supply of required vitamins. Vitamin $\mathrm{B}_{2}$ deficient person has the tendency of the person having the accumulation of fat in the liver which resembles changes normally observed in the liver of chronic alcoholics. In humans with liver cirrhosis, decreased concentration of vitamin $B_{2}$ is found mostly in necrotic regions [56]. Vitamin $\mathrm{B}_{2}$ was low in these samples and would require supplementation from riboflavin rich food sources.

The term niacin has been used generally to encompass the active forms of this vitamin, nicotinic acid and nicotinamide; however, estimates of niacin requirements take into account preformed niacin as well as that obtained as niacin equivalent in the body from tryptophan (Trp) metabolism. Hence, it was estimated that when $60 \mathrm{mg}$ of Trp is consumed by an adult, enough of Trp is oxidized to produce $1.0 \mathrm{mg}$ of niacin [57]. In 1980, RDA of niacin was 6.6 niacin equivalent (NE) per $1000 \mathrm{kcal}$ and intake not less than basic NE had been recommended when the calorie intake is less than $2000 \mathrm{kcal}$; one $\mathrm{NE}$ is equivalent to $1.0 \mathrm{mg}$ niacin (or $60 \mathrm{mg}$ Trp) [58]. Vitamin $\mathrm{B}_{3}$

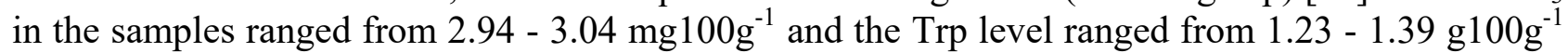
[13] meaning that the samples would be good sources of niacin either directly or indirectly.

The concentration range of the values of vitamin $B_{6}$ was $1.34 \mathrm{e}-1$ to $1.42 \mathrm{e}-1 \mathrm{mg} 100 \mathrm{~g}^{-1}$. Vitamin $\mathrm{B}_{6}$ has many generic names like pyridoxine, pyridoxal and pyridoxamine, the co-enzyme forms of which are pyridoxal phosphate and pyridoxamine phosphate [58]. Vitamin $\mathrm{B}_{6}$ is needed in the synthesis of DNA bases; it is a co-enzyme in the biosynthesis of thymedine. $\mathrm{B}_{6}$ dietary deficiency or an increase in the thymedine requirement at a critical time during cell division could result in initial cell mutations that develop into a tumor [59]. The RDAs were based on a ratio of $0.02 \mathrm{mg}$ of vitamin $\mathrm{B}_{6}$ per gram of protein consumed. From this estimate, the vitamin $\mathrm{B}_{6}$ required to satisfy the protein composition (assuming being main protein source) from the crab flesh would be $0.02 \times 40.2=0.804 \mathrm{mg}$ (female) and $0.02 \times 43.7=0.874 \mathrm{mg}$ (male). These values were low and generally fell below the RDA standards but higher than the levels reported for rosmas variety seeds

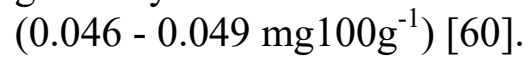

Vitamin $\mathrm{B}_{9}$ (folic acid) is of no consequence in the present results; its values being in the range of $4.07 \mathrm{e}-7$ to $4.54 \mathrm{e}-7 \mathrm{mg} 100 \mathrm{~g}^{-1}$. However where present in reasonable quantity, it has been reported to inhibit growth of tumors $[61,62]$. Folacin, the co-enzyme of vitamin $\mathrm{B}_{9}$ is needed for 
the synthesis of purine and methionine, for the catabolism of histidine, and for the conversion of serine to glycine [58].

Vitamin $\mathrm{B}_{5}$ (panthothenic acid) had values range of $3.44 \mathrm{e}-1$ to $3.73 \mathrm{e}-1 \mathrm{mg} 100 \mathrm{~g}^{-1}$. These values were close to the values of 3.17 e-1 to 4.19 e- $1 \mathrm{mg} 100 \mathrm{~g}^{-1}$ reported for the innards of $N$. maculatus [14]. Recommended dietary allowances (male, age 19 - 70 years) is 5.0mg [63] which is much higher than the present results, hence supplementation may be required.

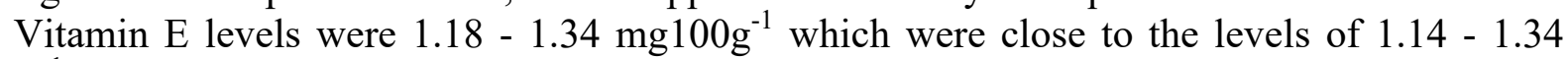
$\mathrm{mg} 100 \mathrm{~g}^{-1}$ in N. maculatus innards [14]. Other names for vitamin E are tocopherols, tocotrienols. The RDA for male (19 - 70 years) is $15.0 \mathrm{mg}$ per day [63]; this is much higher than the crab flesh results. Deficiency is said to be very rare; sterility in males and abortions in females, mild hemolytic anemia in newborn infants.

Vitamin $\mathrm{C}$ is active in the body either as ascorbic acid or as dehydroascorbic acid. There is a clear link between the functions of vitamin $\mathrm{C}$ and its reversible oxidation and reduction properties. Vitamin $\mathrm{C}$ plays important roles in many biochemical reactions involving incorporation of oxygen into the substrate [62]. Also, tissue defense mechanism against free radical damage generally involves vitamin $\mathrm{C}$, vitamin $\mathrm{E}$ and $\beta$-carotene as the major vitamin anti-oxidants in extracellular fluids [64]. The RDA of vitamin $C$ for adults $\left(60\right.$ mgday $\left.^{-1}\right)$ maintains a body pool of $1.5 \mathrm{~g}$ and 10 mgday $^{-1}$ is sufficient to prevent or cure scurvy [57]. The ascorbic acid levels in the present results

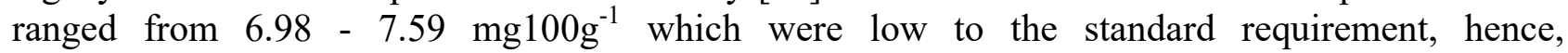
supplementation may be needed. Other vitamins determined but of low concentration were $\mathrm{B}_{4}, \mathrm{~A}$, $\mathrm{B}_{1}$ and $\mathrm{K}$. In Table 11, we have the report of the statistical analysis of the results from Table 10 . These values were high: $r_{x y}, r_{x y}^{2}, R x y, C V \%$ and IFE. Both the mean, standard deviation and the coefficient of alienation were low. The results were significantly different at $r=0.01$ and the prediction of biochemical relationship was also not difficult since the error of prediction was low at $2.64 \%$.

Table 11. Statistical analysis of the results from Table 10

\begin{tabular}{|l|l|l|l|}
\hline Statistics & Male crab & & Female crab \\
\hline $\mathrm{r}_{\mathrm{xy}}$ & & 0.9997 & \\
\hline $\mathrm{r}_{\mathrm{xy}}{ }^{2}$ & & 0.9993 & \\
\hline Rxy & & 1.06 & \\
\hline Mean & 2.02 & & 2.14 \\
\hline $\mathrm{SD}$ & 3.78 & & 4.03 \\
\hline CV\% & 188 & & 188 \\
\hline $\mathrm{C}_{\mathrm{A}}$ & & 0.0264 & \\
\hline IFE & & 0.9736 & \\
\hline Remark & & $*$ & \\
\hline
\end{tabular}

Results significantly different at $n-2(\mathrm{df})(12-2=10) \mathrm{r}_{=0.01} ;\left[\mathrm{r}_{\mathrm{T}}=0.708\right.$ (critical value) $]$.

\section{Conclusions}

Neopetrolisthes maculatus heterosexual flesh samples were found to be low in fat, carbohydrate, fibre but high in protein and ash. The highest energy contribution of the nutrients came from protein and least from fat. The utilization of energy value due to protein was much higher than the recommended value. Dominant macro minerals in the samples were: $\mathrm{Mg}, \mathrm{Ca}, \mathrm{K}, \mathrm{Na}$ and $\mathrm{P}$; nutritionally valuable trace minerals were: $\mathrm{Fe}, \mathrm{Cu}, \mathrm{Zn}, \mathrm{Se}, \mathrm{Mn}$ and $\mathrm{Ni}$; the biochemically toxic metals were $\mathrm{Cd}$ and $\mathrm{Pb}$ which were all significantly very low. No mineral ratio met the acceptable ideal range. In the mineral safety index, $\mathrm{Mg}$ and $\mathrm{Cu}$ were at the deleterious levels. Vitamins with concentration of importance were: $\mathrm{B}_{3}, \mathrm{~B}_{6}, \mathrm{C}, \mathrm{B}_{1}, \mathrm{~B}_{2}, \mathrm{E}$ and $\mathrm{B}_{5}$. The female crab was better concentrated in minerals and vitamins but the male was better in protein concentration. All the parameters investigated were significantly different between the male and the female $N$. maculatus samples at $\mathrm{r}=0.01$. 


\section{Conflict of Interest}

The authors declare that there is no conflict of interest.

\section{References}

[1] J. Haig, The Porcellanidae (Crustacaea, Anomura) of Western Australia with description of four new Australian species, Journal of the Royal Society of Western Australia. 48 (4) (1965) 97-117.

[2] S.T. Ahyong et al., A new classification of the Galatheoidea (Crustacea: Decapoda: Anomura), Zootaxa. 2676 (1) (2010) 57-68.

[3] H. Milnes Edwards, Histoire naturelle des Crustacés, comprenant l'anatomie, la physiologie et al classification de ces animaux, Librairie Encyclopédique de Roret, Paris, 1837.

[4] P. Vine, Red Sea Invertebrates, Immel Publishing, London, 1986.

[5] J. Poupin, M. Juncker, Guide des Crustaces Decapodes du Pacifique Sud/A Guide to Decapod Crustaceans of the South Pacific, CRISP and CPS, Noumea, 2010.

[6] P.J.F. Davie, Crustacea: Malacostraca: Eucarida (Part 2): Decapoda-Anomura, Brachyura, in: A. Wells, W.W.K. Houston (Eds), Zoological Catalogue of Australia. 19 (3B) (2002), CSIRO Publishing, Melbourne.

[7] E.I. Adeyeye, Determination of the chemical composition of the nutritionally valuable parts of male and female common West African fresh water crab Sudananautes africanus africanus, Int. J. Food Sci. Nutr. 53(2002)189-196.

[8] E.I. Adeyeye, Amino acid composition of the whole body, flesh and exoskeleton of female common West African fresh water crab Sudananautes africanus africanus. Pak. J. Nutr. 7 (2008) 748-752.

[9] E.I. Adeyeye, J.O. Olanlokun, T.O. Falodun, Proximate and mineral composition of whole body, flesh and exoskeleton of male and female common West African fresh water crab Sudananautes africanus africanus, Polish J. Food Nutr. Sci. 60(3) (2010) 213-216.

[10] I.O. Elegbede, H.A. Fashina-Bombata, Proximate and mineral compositions of common crab species (Callinectes pallidus and Cardisoma armatum) of Badagry creek, Nigeria. Poultry Fisheries and Wildlife Sciences. 2(2013) 1-5.

[11] M.A. McNiven et al., Composition and distribution of the European green crab in Prince Edward Island, Canada, Open Journal of Animal Sciences. 3 (4) (2013) 295-298.

[12] E.I. Adeyeye, Comparative study of the lipid and fatty acid composition of two shell fish: lagoon and fresh water crabs. Malaya Journal of Biosciences. 2(2015) 57-74.

[13] E.I. Adeyeye, Amino acid profiles of the flesh of the heterosexual pairs of Neopetrolisthes maculatus, International Letters of Natural Sciences. 61(2017) 23-35.

[14] E.I. Adeyeye, T. Jegede, Chemical composition (proximate, minerals, vitamins), mineral ratios and mineral safety index of the innards of male and female Neopetrolisthes maculatus, J. Bio. Innov. 6(3) (2017) 479-498.

[15] D. Pearson, Chemical analysis of foods, $7^{\text {th }}$ ed., J. and A. Churchill, London, 1976.

[16] AOAC, Official Methods of Analysis, $18^{\text {th }}$ ed., Association of Official Analytical Chemists, Washington, DC, 2006.

[17] Varian Techtron, Basic atomic absorption spectroscopy: a modern introduction, Varian Techtron Pty Ltd., Springvale, Australia, 1975.

[18] J. N. Hatcock, Quantitative evaluation of vitamin safety, Pharmacy Times. (1985) 104-135. 
[19] D. L. Watts, HTMA mineral ratios: A brief discussion of their clinical importance, Trace Elements Newsletter. 21(1) (2010) 1-3.

[20] Analytical Research Labs, Inc (ARL), Basic ratios and their meaning, $2225 \mathrm{~W}$ Alice- AvenuePhoenix, Arizona 85021, USA, 2012.

[21] R. A. Oloyo, Fundamentals of research methodology for social and applied sciences, ROA Educational Press, Ilaro, Nigeria, 2001.

[22] C. I. Chase, Elementary statistical procedures, 2nd ed., McGraw-Hill Kogakusha Ltd., Tokyo, Japan, 1976.

[23] E. I. Adeyeye, T. Jegede, Z. Mashood, Proximate, mineral and mineral safety index of Acanthurus monroviae and Lutjanus goreensis fishes, J. Bio. Innov. 5(1) (2016) 107-122.

[24] E. I. Adeyeye, M. A. Oyarekua, Lipid profile of the skin and muscle of fresh water sardine (Pellenula afzeliusi): nutritional/dietary implications, Bang. J. Sci. Ind. Res. 46(4) (2011) 523-532.

[25] E. I. Adeyeye et al., Great Barracuda: its skin and muscle fatty acids, phospholipids and zoosterols compositions, Int .J. Chem. Soc. 5(1) (2012) 18-28.

[26] J. L. Weihrauch et al., Lipid conversion factors for calculating fatty acid contents of foods, Journal of American Oil Chemists' Society. 54(1) (1997) 36-40.

[27] E.I. Adeyeye, M.A. Oyarekua, A.J. Adesina, Proximate, mineral, amino acid composition and mineral safety index of Callinectes latimanus, Int. J. Dev. Res. 4 (12) (2014) 2641-2649.

[28] E.I. Adeyeye, A.M. Kenni, The relationship in the amino acid of the whole body, flesh and exoskeleton of common West African fresh water male crab Sudananautes africanus africanus, Pak. J. Nutr., 7(6) (2008) 748-752.

[29] E.I. Adeyeye, Amino acid profiles of whole organism, flesh and shell of Pandalus borealis (Krøyer 1838). Am. J. Food Sci. Nutr. 2(3) (2015) 31-41.

[30] S.A. Abdullahi, D.S. Abolude, Investigation of protein quality of some fresh water species of northern Nigeria, Acad. J. Sci. Engr. 2(1) (2002) 18-25.

[31] E.I. Adeyeye, A.S. Adamu, Chemical composition and food properties of Gymnarchus niloticus (Trunk fish), Biosci. Biotech. Res. Asia. 3 (2005) 265-272.

[32] J. Sales, J.P. Hayes, Proximate, amino and mineral composition of ostrich meat, Food Chem. 56(2) (1996) 167-170.

[33] E.I. Adeyeye, A.J. Adesina, Proximate, mineral compositions and mineral safety index of eight organs of guinea-fowl (Numidia meleagris), Frontiers in Food Science and Technology. 1(1) (2014) 7-13.

[34] O.V. Fornias, Edible by-products of slaughter animals, FAO Animal Production and Health Paper 123, FAO, Rome, 1996.

[35] A.A. Paul, D.A.T. Southgate, McCance and Widdowson's The Composition of Foods, 4th ed., HMSO, London, 1978.

[36] S. Bingham, Dictionary of Nutrition, Barrie and Jenkins, London, 1977.

[37] E.I. Adeyeye, O.O. Ayejuyo, Proximate, amino acid and mineral composition of turkey-hen muscle and skin, Orient. J. Chem. 23(3) (2007) 879-886.

[38] E.I. Adeyeye, M.O. Aremu, Chemical composition of whole shrimp, flesh and shell of Pandalus borealis from Lagos Atlantic Ocean, FUW Trends in Science and Technology Journal. 1(1) (2016) 26-32. 
[39] NACNE (National Advisory Committee on Nutrition Education), Proposal for nutritional guidelines for healthy education in Britain, Health Education Council, London, 1983.

[40] COMA (Committee on Medical Aspects), Committee on Medical Aspects of Food Policy; Diet and cardiovascular disease, HMSO, London, 1984.

[41] W.D. Snively, Jr., M. Wessener, The ABC's of fluid balance, Journal of Indiana State Med. Assoc. 47(9) (1954) 957-972.

[42] White House Conferences, Growth and development of the child, III, Nutrition, AppletonCentury-Crofts, New York, 1932.

[43] E.L. Pratt, S.E. Snyderman, Renal water requirement of infants fed evaporated milk with and without added carbohydrate, Pediatrics. 11(1) (1953) 65-69.

[44] A. A. Albanese (Editor), Protein and amino acid nutrition, Academic Press, New York and London, 1959.

[45] A. Stella Irin Kumari et al., Determinations of minerals in marine crab Charybdis lucifera (Fabricius 1798), Int. J. Zool. Appl. Biosci. 1(3) (2016) 130-135.

[46] A. Kucukgulmez, M. Celik, Amino acid composition of blue crab (Callinectes sapidus) from North Easthern Mediterranean Sea, J. Appl. Biol. Sci. 2(1) (2008) 39-42.

[47] F. Camara, M.A. Amaro, R. Barbera, G. Clemente, Bioaccesibility of minerals in school meals; comparison between dialysis and solubility methods, Food Chem. 92 (2005) 481-489.

[48] H. Fleck, Introduction to nutrition, 3rd ed., Macmillan, New York, 1976.

[49] Y. Yannar, M. Celik, Seasonal amino acid profiles and mineral contents of green tiger shrimp (Penaeus seminsulcatus De Haan, 1844) and speckled shrimp (Metapenaeus monoceros, Fabricius, 1789) from the eastern Mediterranean, Food Chem. 94 (2006) 33-36.

[50] FAO/WHO, Human vitamins and mineral requirements, Report of joint Food and Agricultural Organization of the United Nations/World Health Organization Expert Consultation, Bankok, Thailand, 2002.

[51] G. Luquet, F. Marin, Biomineralization in crustaceans: storage strategies, Comptes Rendus Palevol. 3 (6-7) (2004) 515-534.

[52] NAS, Food and Nutrition Board: Recommended dietary allowances. In: Introduction to Nutrition, 3rd ed., editor: H. Fleck, Macmillan, New York, pp. 11-17, 1974.

[53] D.M. Hegsted, Calcium and phosphorus. In: Modern nutrition in health and disease, ch.6, sect. A, Lea and Febiger, Philadelphia, PA, 1973.

[54] Food and Nutrition Board, National Research Council, Recommended Dietary Allowances, 10th ed., National Academy Press, Washington D.C., 1989.

[55] G.R. MacFarlane, D.J. Booth, K.R. Brown, The semaphore crab, Heliocius cordiformis: Bioindication potential for heavy metals in estuarine systems, Aquat. Toxicol. 50 (2000) 153166.

[56] D.W. Chen, M. Zhang, Analysis of volatile compounds in Chinese mitten crab (Eriocheir sinensis), J. Food Drug Anal. 14 (3) (2006) 297-303.

[57] NRC (National Research Council), Recommended dietary allowances, 9th ed., Report of the sciences: Assembly of Life Sciences, National Academy Press, Washington D.C., 1980.

[58] NRC (National Research Council), Recommended daily allowances, 10th ed., National Academy Press, Washington D.C., U.S.A., 1989.

[59] F.G. Prior, Theoretical involvement of vitamin $B_{6}$ in tumor initiation, Medical Hypotheses. 16 (1985) 167-170. 
[60] A.B. Gwana et al., Determinations of phytochemicals, vitamins, minerals and proximate compositions of varieties of watermelon seeds cultivated in Borno State, North-Eastern Nigeria, Int. J. Nutr. Food Sci. 3(4) (2014) 238-245.

[61] R.L. Prentice et al., Rationale and design of cancer chemoprevention studies in Seatle, National Cancer Institute Monograph. 62 (1985) 249-258.

[62] R.M. Lee, Vitamin in animal and human health, 2nd ed., Iowa State University Press, 2121 Southern State Avenue, Anes, Iowa 50014, 2000.

[63] The National Academies, Dietary Reference Intakes: Vitamins, The National Academies Press, Washington, D.C., 2001.

[64] R. Stocker, B. Frei, Endogenous antioxidant defences in human blood plasma, in: Oxidative stress: oxidants and antioxidants, Edited by H. Sies, Academic Press, London, U.K, 1961, pp. 213-243 